\title{
Effects of turbulence on the composition of phytoplankton assemblages in marine microcosms
}

\author{
Marta Estrada, Miquel Alcaraz \& Celia Marrasé
}

Institut de Ciències del Mar, P. Nacional, s/n, 08003 Barcelona, Spain

\begin{abstract}
Changes in composition of natural phytoplankton assemblages enclosed in $30 \mathrm{dm}^{3}$ cylindrical culture vessels were followed under different conditions of water stirring. Experiments were started at different times of the year with seawater taken off Masnou ( $20 \mathrm{~km}$ north of Barcelona, Spain) and each treatment was assayed in 2 replicates. Enclosure of phytoplankton assemblages was followed in general by a pronounced increase in chlorophyll concentration and phytoplankton abundance due to proliferation of centric diatoms. As nutrients were consumed, phytoplankton abundance decreased and the diatoms were substituted by coccolithophorids, dinoflagellates and flagellates. Different stirring treatments affected the timing and intensity of the initial population peak and induced repeatable (within each experiment) changes in the composition of the phytoplankton assemblages of the later phases of the experiments.
\end{abstract}

\section{INTRODUCTION}

The variety of forms that can be found in natural communities of phytoplankton has repeatedly attracted the attention of ecologists. According to Margalef (1978), the best predictor of dominant phytoplankton life-forms is the availability of external energy. Some of the main phytoplankton life-forms in the marine environment coincide basically with major taxonomic groups (diatoms, dinoflagellates, coccolithophorids) and can be ordered (Margalef 1978) in a sequence ranging from organisms dominating in turbulent, fertile environments (diatoms) to those found in stratified, nutrient-poor waters (typically dinoflagellates). This sequence was represented graphically by Margalef et al. (1979) in an ecological space (the 'phytoplankton mandala') defined by functions of the intensity of turbulence (represented by $D$, the eddy diffusivity coefficient) and $\alpha$, the growth rate of the phytoplankton population, which depends on light and nutrient availability. Bowman et al. (1981) illustrated the conceptual equivalence of Margalef's mandala with Pingree's $s$ - $k h$ diagram (Pingree 1978), where $s$ is a stratification parameter and $k h$ represents the water column depth $(h)$ scaled in relation to transparency ( $k$ is the diffuse extinction coefficient).

A large body of laboratory research has dealt with the response of diverse species or strains of phytoplankton algae to different light and nutrient condi- tions (see e. g. reviews in Morris 1980). However, few studies have examined experimentally the influence of turbulent movements of the water on phytoplankton populations (e. g. Schöne 1970, Eppley et al. 1978, Sonntag \& Parsons 1979, Nixon et al. 1980, Oviatt 1981, Savidge 1981, Harris 1983, Reynolds et al. 1983). In addition, the problems associated with quantification of turbulence and the variety of methodological approaches make very difficult any integration of the available results.

Given the impossibility of controlling the movement of the water in natural ecosystems, most of the research work on turbulence has been based on the enclosure of phytoplankton populations in containers ranging from large plastic bags limiting in situ a column of water of many $\mathrm{m}^{3}$ in a lake or in the sea (Perez et al. 1977, Grice et al. 1980, Nixon et al. 1980, Pilson \& Nixon 1980, Gamble \& Davies 1982) to culture vessels of a few $\mathrm{cm}^{3}$. Within this spectrum, the utilization of intermediatesized (10 to $1000 \mathrm{dm}^{3}$ ) ecosystem models (microcosms) allows more possibilities for manipulation than large enclosures and a better approximation to certain aspects of the natural system than the smallest containers. In this paper, we deal with a series of experiments carried out with the aim of ascertaining repeatable effects of different levels of environmental turbulence on marine phytoplankton populations enclosed in 30 $\mathrm{dm}^{3}$ microcosms. On the basis of previous experiments in our laboratory (Margalef 1963, Estrada 1976), we 
decided to use cylindrical culture vessels $1200 \mathrm{~cm}$ height $\times 15 \mathrm{~cm}$ diameter) made of Perspex, which were stirred in different ways. We did not attempt to produce a reduced model of a natural marine ecosystem. Our approach was the design of an arrangement allowing experimentation with environmental factors - in this case, turbulence - of possible importance in natural conditions. Although stirring and turbulence refer to different concepts, we assumed that increasing stirring of the medium produced increasing levels of turbulent mixing.

\section{MATERIAL AND METHODS}

Experimental set-up. Experiments were started at different times of the year to evaluate the influence of the initial population on the observed succession. The water for filling the experimental vessels was taken from the mouth of Masnou Harbour, $20 \mathrm{~km}$ north of Barcelona, on 16 Jun 1981 (Expt 3), 28 Oct 1981 (Expt 4), 24 Feb 1982 (Expt 5) and 9 Jun 1982 (Expt 6). (Expts 1 \& 2 were pilot assays not described here.) Before its transfer to the tubes, the water was filtered through a $150 \mu \mathrm{m}$ mesh-size plankton net. In this way, most adult zooplankters were excluded, although larval stages and ciliates passed through.

The tubes employed as culture vessels $(200 \mathrm{~cm}$ high, $15 \mathrm{~cm}$ diameter) were installed in a constant temperature chamber. Four $20 \mathrm{~W}$ fluorescent lamps, $60 \mathrm{~cm}$ long, were placed along the upper part of each tube (Fig. 1).
The lights were turned on for $12 \mathrm{~h}$ (from 0800 to $2000 \mathrm{~h}$ ) each day. No nutrients were added, except for 2 occasions in the later phases of Expt 3.

All stirring treatments (except one) were made in duplicate, to estimate the variability of the results. Expt 3 included 8 tubes; 2 of them were maintained without agitation (S0 tubes). The 3 remaining pairs were stirred with 2 circular pieces of netlon netting of $6 \mathrm{~mm}$ mesh size, which were moved up and down rhythmically by means of a small motor along the illuminated parts of the tubes (Fig. 1). Different oscillation frequencies (21, 45 and $70 \mathrm{~min}^{-1}$ ) were used for each pair of these tubes, which will be refered to as $\mathrm{S} 21, \mathrm{~S} 45$ and $\mathrm{S} 70$, respectively.

In Expt 4, new stirring mechanisms were assayed to investigate possible effects of variations, not only quantitative, but also presumably qualitative, of the turbulence spectrum produced. Two of the tubes (S20) were stirred using a system similar to that described for Expt 3 , but with only one net per tube (moving at 20 oscillations $\min ^{-1}$ ). Two other tubes (S40) were stirred with 2 circular pieces of netlon netting each (one of $6 \mathrm{~mm}$ and another of $12 \mathrm{~mm}$ mesh-size) moving at 20 and 45 oscillations $\mathrm{min}^{-1}$, respectively. Another tube (S60; no duplicate could be prepared for this treatment) was strongly mixed by means of a rotating shaft provided with an elliptical net, with diameters of 12 and $16 \mathrm{~cm}$, inclined $30^{\circ}$ to the vertical axis (Fig. 1). The last 2 tubes were left without agitation.

The last experiments (Expts 5 and 6) were planned to study the effects of medium turbulence in relation to
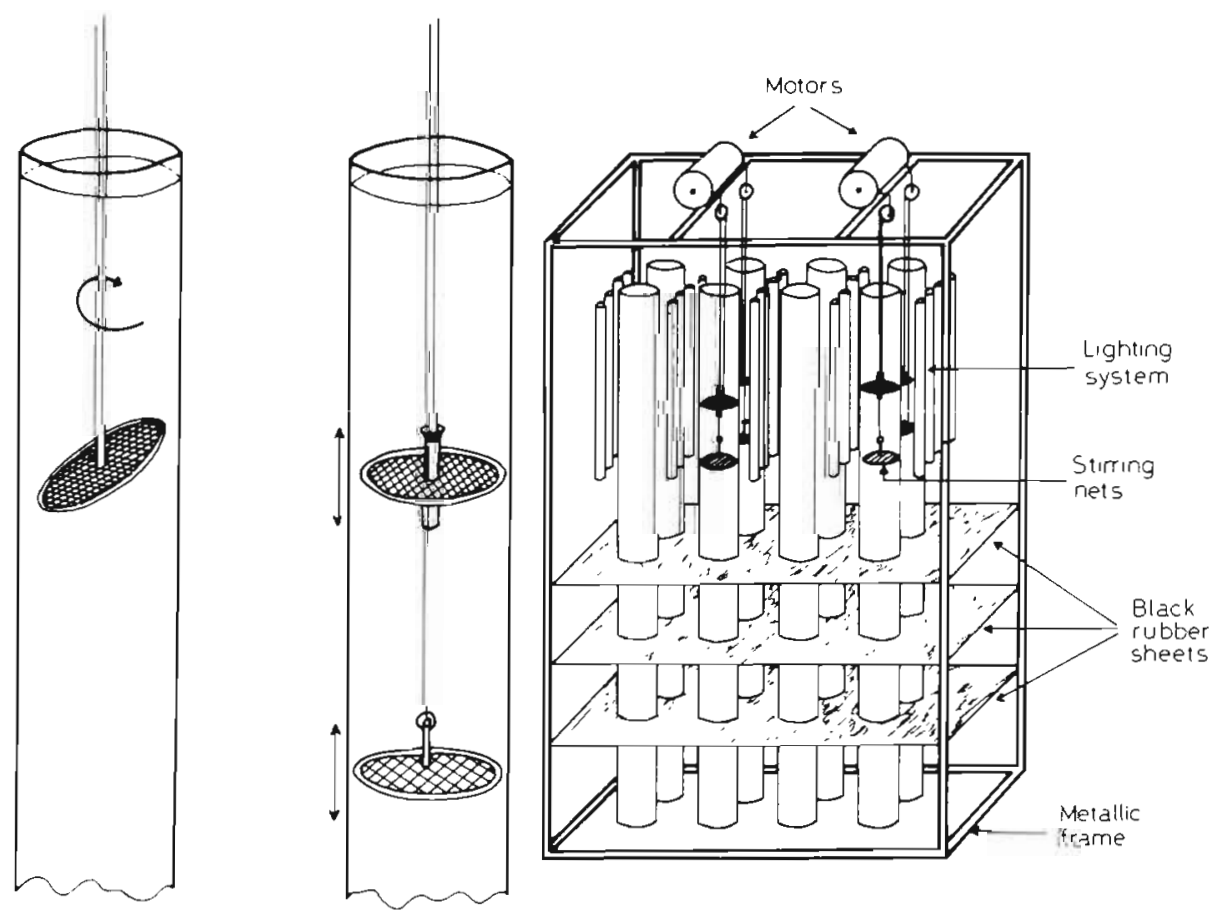

Fig. 1. Microcosm set-up. Left: Rotating grid in Tube S60 of Expt 4. Center: Oscillating grids in the S40 tubes of Expts 4,5 and 6. Right: Schema of the 8 microcosms in Expt 5 
other factors of ecological importance, such as the population density of zooplankton predators (Expt 5) or the position of the irradiance gradient in the culture vessels (Expt 6). These aspects of the experiments will be dealt with elsewhere. However, in both Expts 5 and 6 , two of the tubes were left without stirring and two were stirred like the $\mathrm{S} 40$ pair of tubes described for Expt 4 (in all cases, we will refer to this treatment as S40). Data from the unstirred (SO) and S40 tubes were used to study the influence of the initial population on the evolution of the microcosm.

During the experiments, samples were taken from each tube at 40 and $145 \mathrm{~cm}$ depth (measured from the initial water level) for analysis of nutrients and chlorophyll $a$, phytoplankton counts and study of the particle concentration and size distribution (in 14 channels) with a Coulter Counter. Sampling was done twice a week at the beginning of the experiments and less frequently in the later phases. On several occasions during each experiment, vertical profiles of temperature (with a Crison sensor) and photosynthetically active irradiance (with a Li-cor quantum sensor) were obtained. The vertical distribution of temperature depended (Fig. 2) on the stirring rate; in the stirred

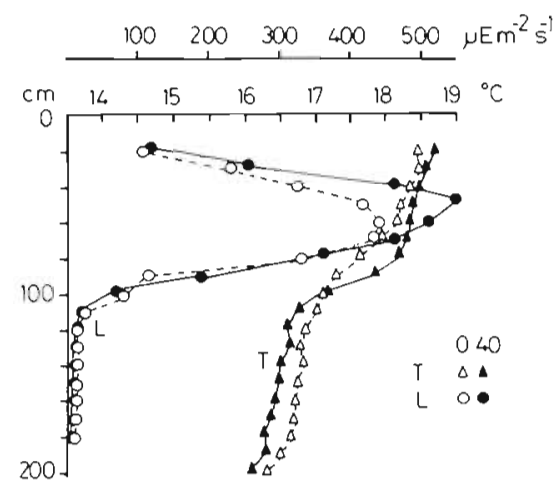

Fig. 2. Typical profiles of temperature (T) and photosynthetically active radiation (L) for unstirred ( $\mathrm{S} 0$ ) and stirred (S40) tubes in Expt 6

tubes, the thermocline was more pronounced and its position became deeper with increasing stirring rates; in the unstirred tubes, a thermocline appeared 60 to $80 \mathrm{~cm}$ below the water surface. In the tubes provided with a rotating net ( $\mathrm{S} 60$ of Expt 4), the temperature was practically the same at all depths.

An example of a typical irradiance profile in the tubes is shown in Fig. 2. The dark, lower part of the tubes was considered as a sink for sedimented phytoplankton cells; the vertical light gradient attempted to take into account the possibility of loss of cells to zones not favourable for growth.

It is difficult to evaluate the magnitude of turbulence in the experimental containers. Turbulence is generally parameterized using eddy diffusivity coefficients (D) whose estimated values at sea are typically several orders of magnitude greater in the horizontal than in the vertical plane (Okubo 1976). In a separate experiment, one of us (Marrasé 1986) and J. Flos (unpubl. data) attempted to estimate $D_{z}$ (the vertical eddy diffusivity coefficient) in unstirred and stirred (S40) tubes, by adjusting a numerical model to sequential data on the vertical distribution of small (14 and $20 \mu \mathrm{m}$ diameter) latex balls added to the top of the tubes. There are several problems to that approach, one of them the fact that the presence of the tube walls alters the relationship between vertical and horizontal turbulence that could otherwise have been expected. Preliminary estimates for $D_{z}$ at $40 \mathrm{~cm}$ depth were about 0.5 $\mathrm{cm}^{2} \mathrm{~s}^{-1}$ for the unstirred and 1 to $5 \mathrm{~cm}^{2} \mathrm{~s}^{-1}$ for the stirred tubes.

Chemical and biological determinations. Concentrations of nitrate, nitrite, phosphate and silicate were determined by means of a Technicon autoanalyzer, using the methods of Strickland \& Parsons (1972). Samples were frozen after extraction because the analyses could not be made immediately. Chlorophyll a was analyzed fluorimetrically (Yentsch \& Menzel 1963, Strickland \& Parsons 1972).

The phytoplankton samples were fixed with concentrated Lugol's solution (without acetic acid). Counts were made by the inverted microscope technique, using $10 \mathrm{~cm}^{3}$ settling chambers. Many of the forms could not be classified at the species level, and vague categories such as 'flagellates', 'small dinoflagellates' or 'cryptomonads' had to be used. The samples were counted within few days of their collection, except in the case of Expt 6, in which the delay was about 2 mo. This may have caused the loss of some delicate cells. Other problems associated with phytoplankton counting have been discussed by Margalef (1972).

Statistical analyses. Principal components analysis (Cooley \& Lohnes 1971, Allen \& Koonce 1973, Blasco et al. 1981, Estrada 1982, Legendre \& Legendre 1983) was used to summarize the information contained in the phytoplankton inventories. The analyses were based on the correlation matrix among the abundances (after logarithmic transformation) of the most frequent species or groups. Runs were made separately for each experiment and for the ensemble of the S0 (unstirred) and S45 (Expt 3) or S40 (Expt 4,5 and 6) duplicates of all the experiments. The combined analysis included 19 frequent taxa found in at least 3 experiments.

Temporal series covering approximately the same length of time (the last samples of the longest experiments were excluded) of the S0 and S45 or S40 duplicates were subjected to a canonical population analysis (Cuadras 1981, Legendre \& Legendre 1983). The 16 populations ( 4 experiments $\times 2$ treatments $\times 2$ duplicates) did not fulfill the condition of homogeneity 
of the variances, necessary to apply statistical tests of significance, so the canonical population analysis was used only as a descriptive tool to point out the main
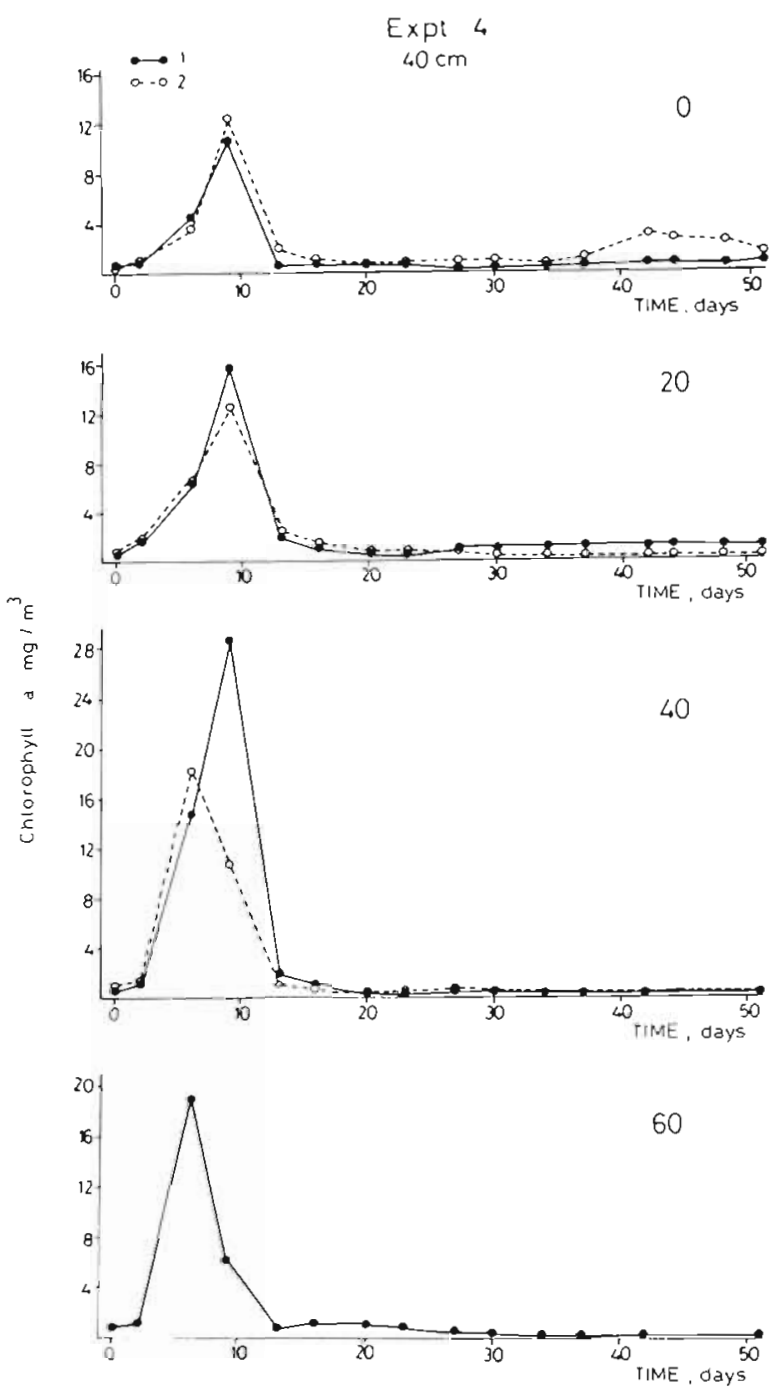

taxa accounting for the differences among the considered populations (Oviatt et al, 1980).

Calculations were carried out on the Digital PDP

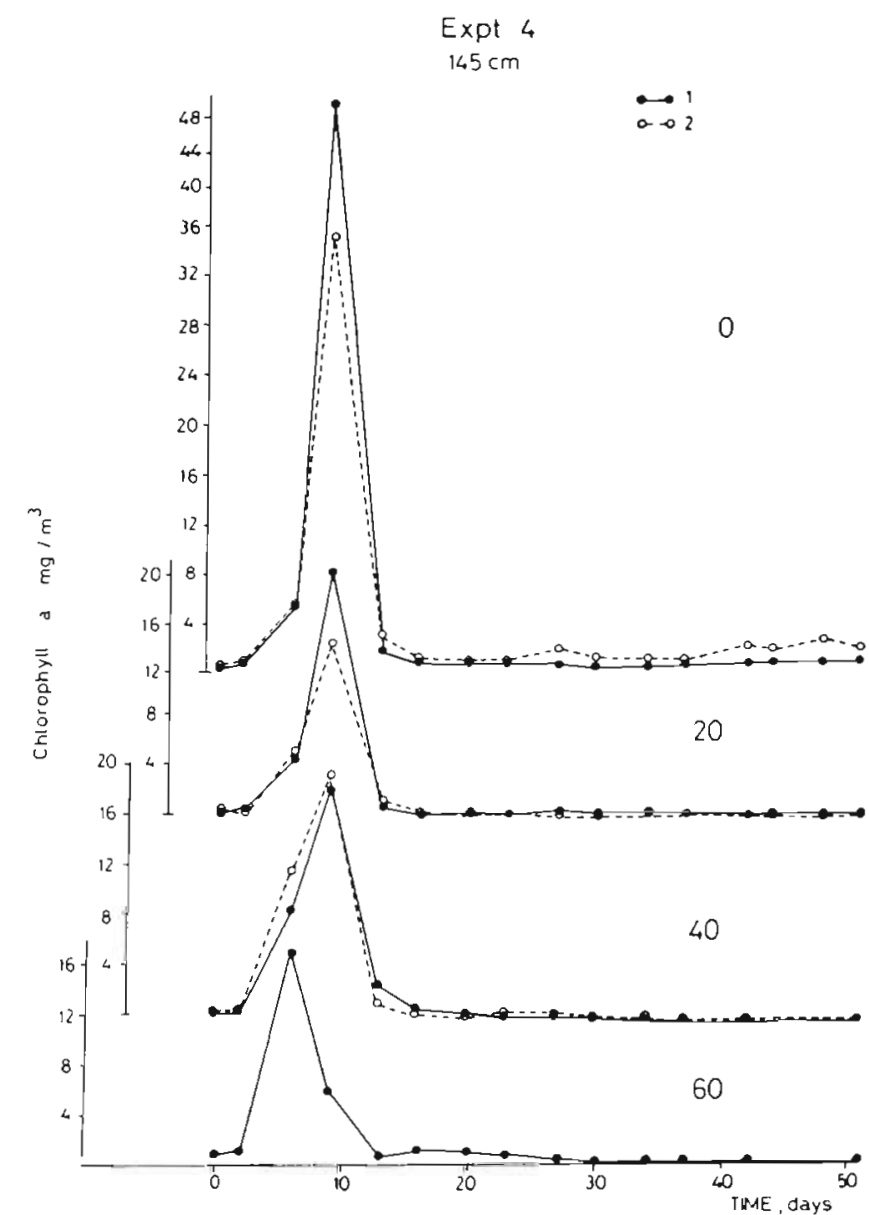

Fig. 3. Expt 4. Temporal variation of chlorophyll concentration at 40 and $145 \mathrm{~cm}$ depth in the pairs of unstirred (SO) and stirred $(\$ 20, \$ 40$ and $\mathrm{S} 60)$ tubes

Table 1. Starting values of nitrate, nitrite, phosphate, silicate, chlorophyll a and phytoplankton density. Expt 3: Nutrient concentrations in the initial seawater Chlorophyll and phytoplankton from samples taken at surface of the 8 tubes, $1 \mathrm{~d}$ after the start of the experiment, when there had already been a redistribution of motile cells along the tubes (see text); only the range of values is given. Expts 4,5,6: Average values from 40 and $145 \mathrm{~cm}$ depth, immediately after filling the tubes. No. of observations is 16, except where given in parentheses

\begin{tabular}{|c|c|c|c|c|c|c|c|c|}
\hline \multirow[t]{2}{*}{ Experiment } & \multirow[t]{2}{*}{ Nitrate } & \multirow[t]{2}{*}{ Nitrite } & \multirow[t]{2}{*}{ Phosphate } & \multirow[t]{2}{*}{ Silicate } & \multirow{2}{*}{$\begin{array}{c}\mathrm{Chl} \mathrm{a} \\
\left(\mathrm{mg} \mathrm{m}^{-3}\right)\end{array}$} & \multirow[t]{2}{*}{ Total } & \multicolumn{2}{|c|}{ Phytoplankton (cells $\mathrm{ml}^{-1}$ ) } \\
\hline & & & & & & & Diatoms & Dinotlageli. \\
\hline \multicolumn{9}{|l|}{ Expt 3 (16 Jun 1981) } \\
\hline Initial seawater & 6.80 & 0.24 & 0.93 & 7.70 & & & & \\
\hline $\begin{array}{l}\text { Tubes ( } 1 \mathrm{~d} \text { after } \\
\text { filling) }\end{array}$ & & & & & $2.7-8.9$ & $6582-10846$ & $214-831$ & $240-1791$ \\
\hline Expt 4 (28 Oct 1981) & $9.86 \pm 0.15$ & $0.58 \pm 0.01$ & $0.58 \pm 0.01$ & $5.76 \pm 0.18$ & $0.48 \pm 0.15$ & $193 \pm 9$ & $23 \pm 9$ & $5 \pm 3$ \\
\hline Expt 5 (24 Feb 1982) & $10.44 \pm 0.12$ & $1.16 \pm 0.02$ & $1.59 \pm 0.04$ & $21.13 \pm 0.70$ & $0.67 \pm 0.02$ & $304 \pm 45$ & $113 \pm 20$ & $0.15 \pm 0.05$ \\
\hline Expt 6 (9 Jun 1982) & $\begin{array}{l}7.81(14) \\
\pm 0.35\end{array}$ & $\begin{array}{l}0.79(15) \\
\pm 0.07\end{array}$ & $\begin{array}{l}1.69(15) \\
\pm 0.06\end{array}$ & $\begin{array}{c}1.63(25) \\
\pm 0.17\end{array}$ & $2.30 \pm 0.04$ & $6775 \pm 1100$ & $5306 \pm 726$ & $105 \pm 33$ \\
\hline
\end{tabular}


11-24 computer of the Institut de Ciències del Mar of Barcelona. The programs for the principal components analysis were modified from IBM (1969). The program for the canonical population analyses, implemented by C. Cuadras (pers. comm.), was adapted to the PDP 11 24 by A. Castellón.

\section{RESULTS}

\section{Effects of stirring treatments on chlorophyll concentration and cell numbers}

The enclosure of a natural population of phytoplankton in the tubes was followed by rapid changes in the biological and chemical parameters measured. The pattern of these changes was very similar in the 2 replicates of each treatment.

In the experiments started with relatively low chlorophyll and high nutrient concentrations (Expts 4, 5 and to some extent Expt 6; Table 1), chlorophyll increased in all tubes at the beginning, reached a maximum 5 to $8 \mathrm{~d}$ later and decreased to relatively low levels that persisted, with small variations, until the termination of the experiments. Nutrients showed a pronounced initial decrease and remained at low values (close to $0.5 \mu \mathrm{M}$ for nitrate and lower than $1 \mu \mathrm{M}$ for silicate) thereafter, except in the case of additions (Days 16 and 23 of Expt 3). On some occasions, phosphate showed slight concentration increases in the middle of the experiments, presumably due to regeneration processes. In all cases, as can be seen from Table 1 , the initial N/P ratio (in atoms) was lower than 16 , the value accepted as typical of marine phytoplankton (Redfield 1958). This suggests a possible limiting role of nitrogen following nutrient consumption.

Temporal changes in chlorophyll concentration were similar for both depths sampled, except for quantitative differences and lags in the appearance of the lower depth maxima, derived from the upper layers by sedimentation.

Within the general patterns described, the details of the chlorophyll variation differed for each stirring treatment. In Expt 4 (Fig. 3), the maximum appeared $6 \mathrm{~d}$ after the start in Tubes S0, S20 and in one of the S40, and on the fifth day in the other S40 and in the S60. The rate of chlorophyll increase after the second day was higher in both S40 tubes and in the S60. However, as the sampling interval was 2 to $3 \mathrm{~d}$, the significance of the differences in the timing of the peaks is difficult to evaluate. In Expts 5 and 6 (Fig. 4 \& 5), the chlorophyll maxima appeared $5 \mathrm{~d}$ after the start of the experiment in all tubes, but the decrease in the chlorophyll concentration after the initial peak was faster in the unstirred ones. Point to point differences in the chlorophyll con-

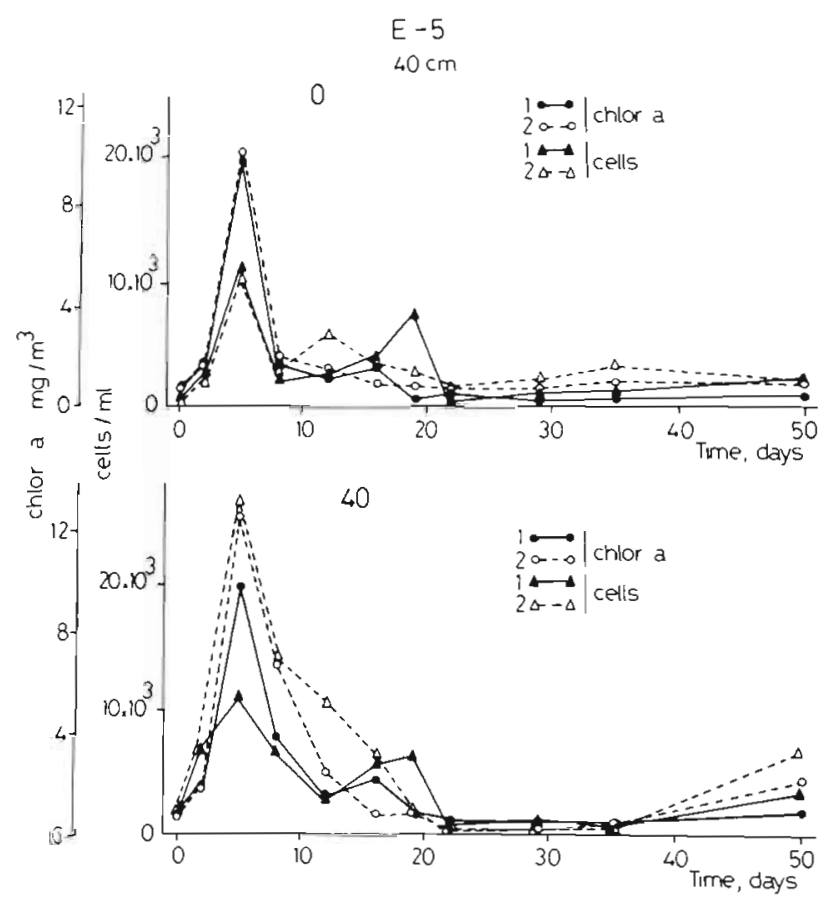

Fig. 4. Expt 5. Temporal variation of concentration of chlorophyll and phytoplankton at $40 \mathrm{~cm}$ depth in the unstirred (S0) and stirred (S40) tubes

centrations attained in the different treatments cannot be reliably compared; however, an examination of the chlorophyll series suggests the presence of higher overall concentrations in the stirred tubes. This point has been examined in detail by Marrasé (1986).

The variation of the chlorophyll concentration in Expt 3 showed some particular characteristics. Chlorophyll values decreased from the beginning in the upper layer of all tubes except both $\$ 70$, where they presented a maximum on the fifth day (Fig. 6). At 145 $\mathrm{cm}$ depth, the concentration of chlorophyll remained more or less stationary in the S0, S21 and S45 tubes, but showed a peak in the S70. The increases at the end of the experiment were due to nutrient additions (194 $\mu \mathrm{mol}$ per tube of nitrate on Day $16 ; 750 \mu \mathrm{mol}$ per tube of ammonia, $1300 \mu \mathrm{mol}$ of nitrate, $54 \mu \mathrm{mol}$ of phosphate, $150 \mu \mathrm{mol}$ of silicate and $1.5 \mathrm{ml}$ of the EDTA-metal mixture described in Blasco [1971] on Day 23). As will be discussed below, the analysis of the phytoplankton composition in the tubes of Expt 3 suggested that the initial variations of the chlorophyll concentration at 40 and $145 \mathrm{~cm}$ depth could be related to a population of relatively large dinoflagellates capable of regulating their position in the water column.

The variations of the total number of phytoplankton cells were comparable to those of the chlorophyll concentration, with discrepancies which could generally be accounted for by changes in the proportions of species with different cell sizes. In general, the com- 


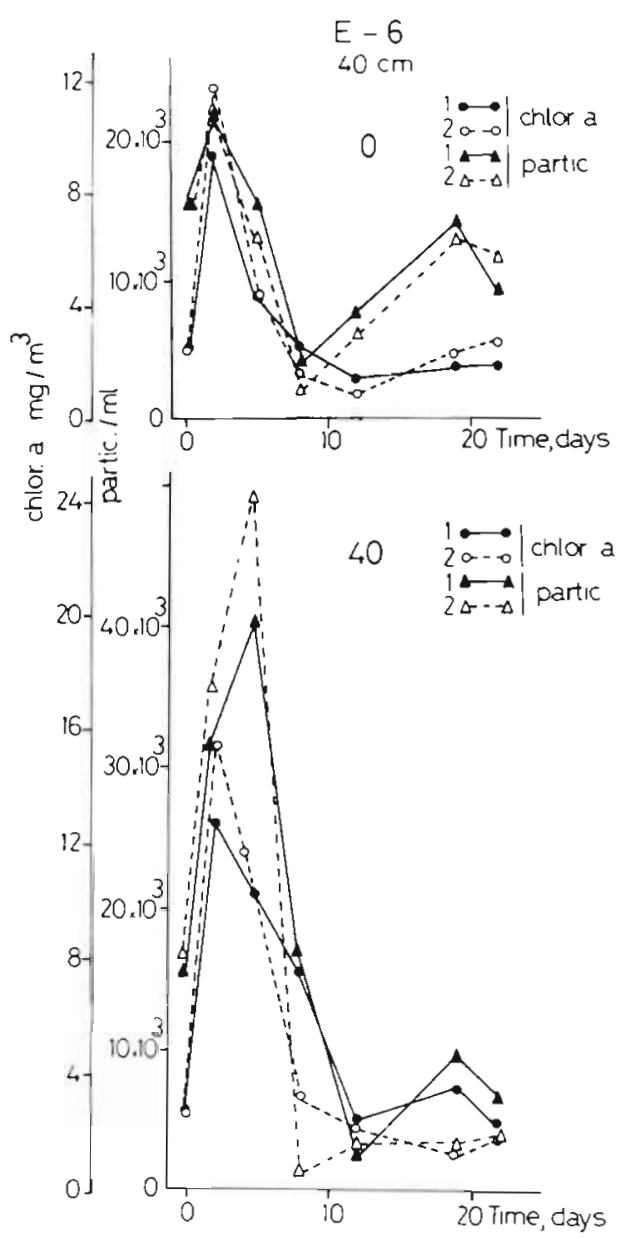

Fig. 5. Expt 6. Temporal variation of concentration of chlorophyll and particles at $40 \mathrm{~cm}$ depth in the unstirred (SO) and stirred $(\mathrm{S} 40)$ tubes

position of the phytoplankton populations at 40 and 145 $\mathrm{cm}$ depth was very similar.

In the experiments started with relatively low chlorophyll concentration (Table 1: Expts 4 and 5), the initial cell and chlorophyll peak was due chiefly to the proliferation of centric diatoms (Chaetoceros spp., Thalassiosira spp., Leptocylindrus danicus, Skeletonema costatum, etc.). In Expt 4, the net growth rates ( $\left[\ln \mathrm{N}_{\mathrm{t}}-\ln \mathrm{N}_{0}\right] / \mathrm{t}$ ) derived for $S$. costatum in the interval between the first and second sampling $(2 \mathrm{~d})$ ranged between 1.5 and $2.6 \mathrm{~d}^{-1}$, corresponding to doubling times between 0.46 and $0.31 \mathrm{~d}$. These values are somewhat smaller than maximum rates reported in the literature $\left(\mathrm{r}=2.3\right.$ to $2.4 \mathrm{~d}^{-1}$ ) for cultures of $S$. costatum (Jitts et al. 1964, Jörgensen 1968). Possibly, the initial growth rate had already decreased before the second sampling in the tubes, but it must be considered also that the calculated net growth rate represents the difference between a reproduction and a loss rate.

In Expt 6, started (Table 1) with higher chlorophyll
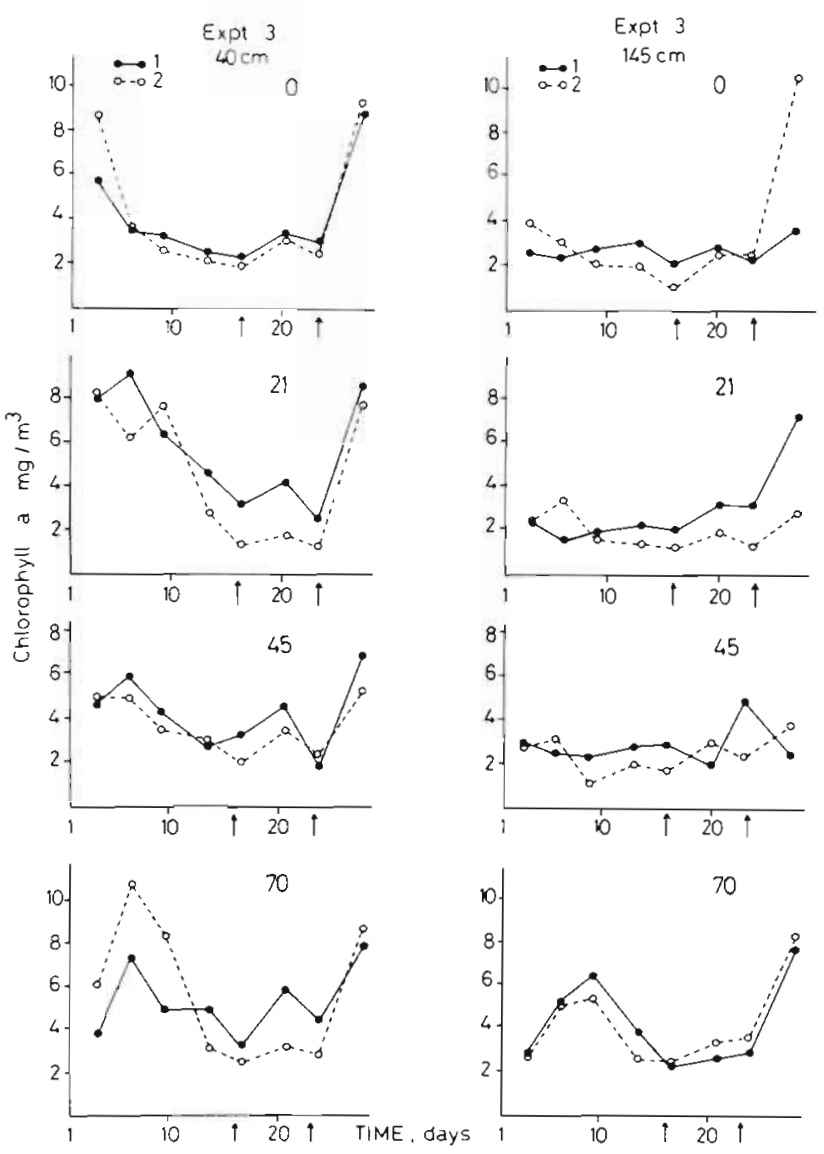

Fig. 6. Expt 3. Temporal variation of chlorophyll concentration at 40 and $145 \mathrm{~cm}$ depth in the pairs of unstirred (SO) and stirred (S21, S45 and S70) tubes. Arrows indicate nutrient additions (nitrate on Day 16 and nitrate, ammonia, phosphate, silicate and EDTA-metal mixture on Day 23)

concentration than Expts 4 and 5, initial diatom numbers were already very high and decreased sharply after the second sampling. In general, total cell numbers increased coinciding with the chlorophyll maximum, but there were exceptions; in this case, as some samples were counted after several weeks, the deterioration of small chlorophyll-containing forms cannot be excluded. Particle counts showed a marked peak parallel to that of chlorophyll (Fig. 5).

In the experiments discussed above, the presence of the diatoms forming the bulk of the initial bloom was ephemeral, and later on the phytoplankton community became dominated by haptophytes (including, on occasions, Emiliania huxleyi), dinoflagellates and small flagellates. However, some small diatoms, like Cylindrotheca closterium, may present moderate population increases in advanced stages of the microcosm succession.

In Expt 3, started with high phytoplankton biomass (Table 1), the population was always dominated by 
dinoflagellates, although there were limited proliferations of the diatoms Chaetoceros cf. simplex and Skeletonema costatum at the beginning and in the middle of the experiment, respectively.

\section{Effects of stirring treatments on phytoplankton composition}

The different stirring treatments used in Expts 3 and 4 induced repeatable (within each pair of duplicates) changes in the composition of the phytoplankton assemblages in the advanced phases of the experiments. The stirring regime affected also the relative concentration of the dominant species in the initial peaks, but these effects were less apparent.

The population densities of the main phytoplankton groups during Expts 3 and 4 are shown in Fig. $7 \& 8$. Some global differences among treatments can be seen easily, but a better characterization of the trends of variability of the phytoplankton composition was obtained using principal component analysis. Separate analyses were performed with the $40 \mathrm{~cm}$ depth samples and with the complete sets of 40 and $145 \mathrm{~cm}$ samples. The results were similar, but, as could be expected, the effects of the treatments appeared more clearly in the $40 \mathrm{~cm}$ groups, and the following comments will refer, for each experiment, to these results.
Fig. 7. Expt 3. Temporal variation of concentration of total phytoplankton, diatoms and dinoflagellates at $40 \mathrm{~cm}$ depth in the unstirred (S0) and stirred (S21, S45 and S70) tubes

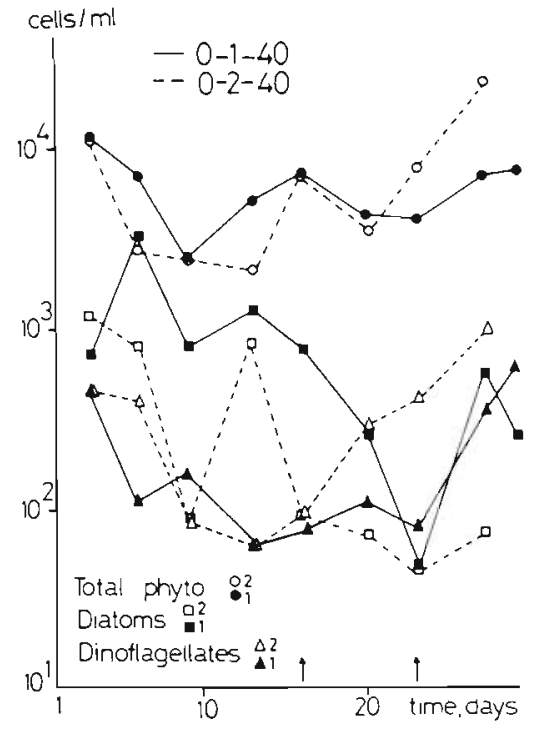

Expt 3

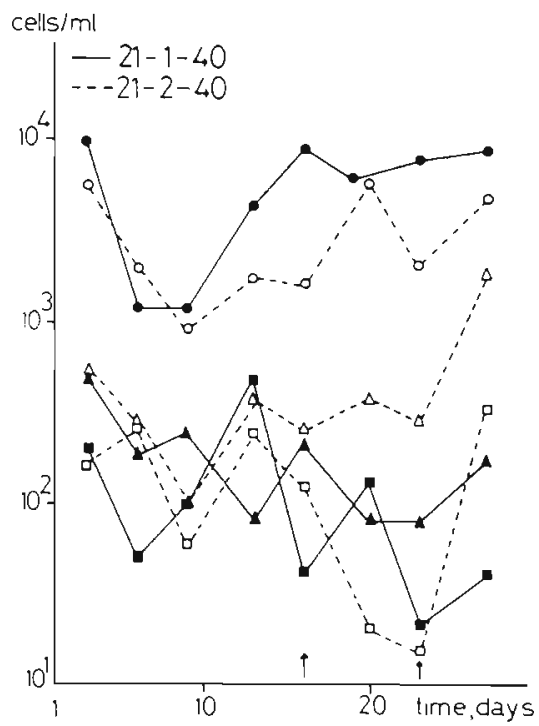

Expt 3

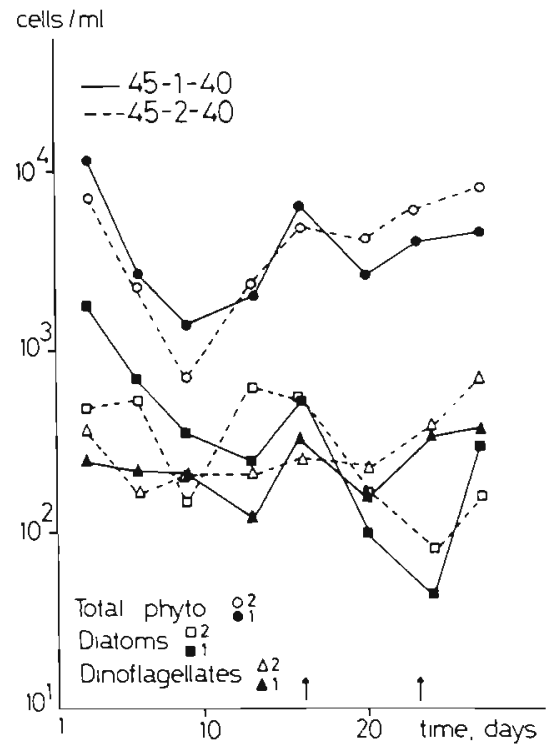

ceils/ml

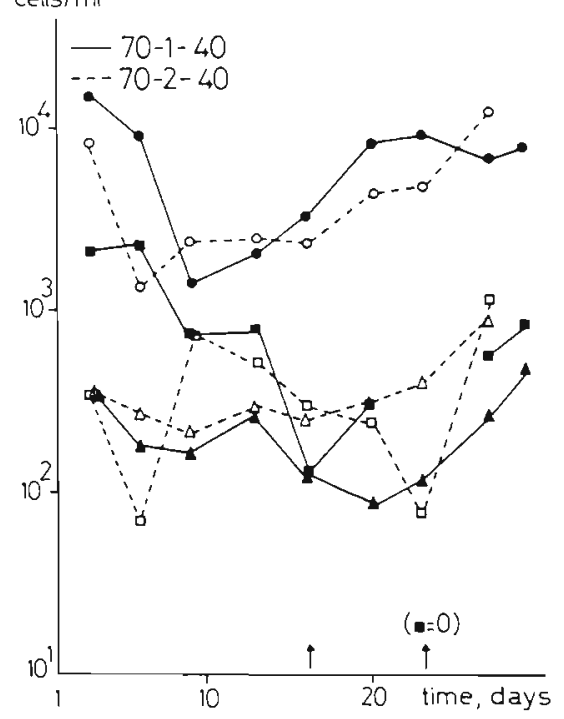



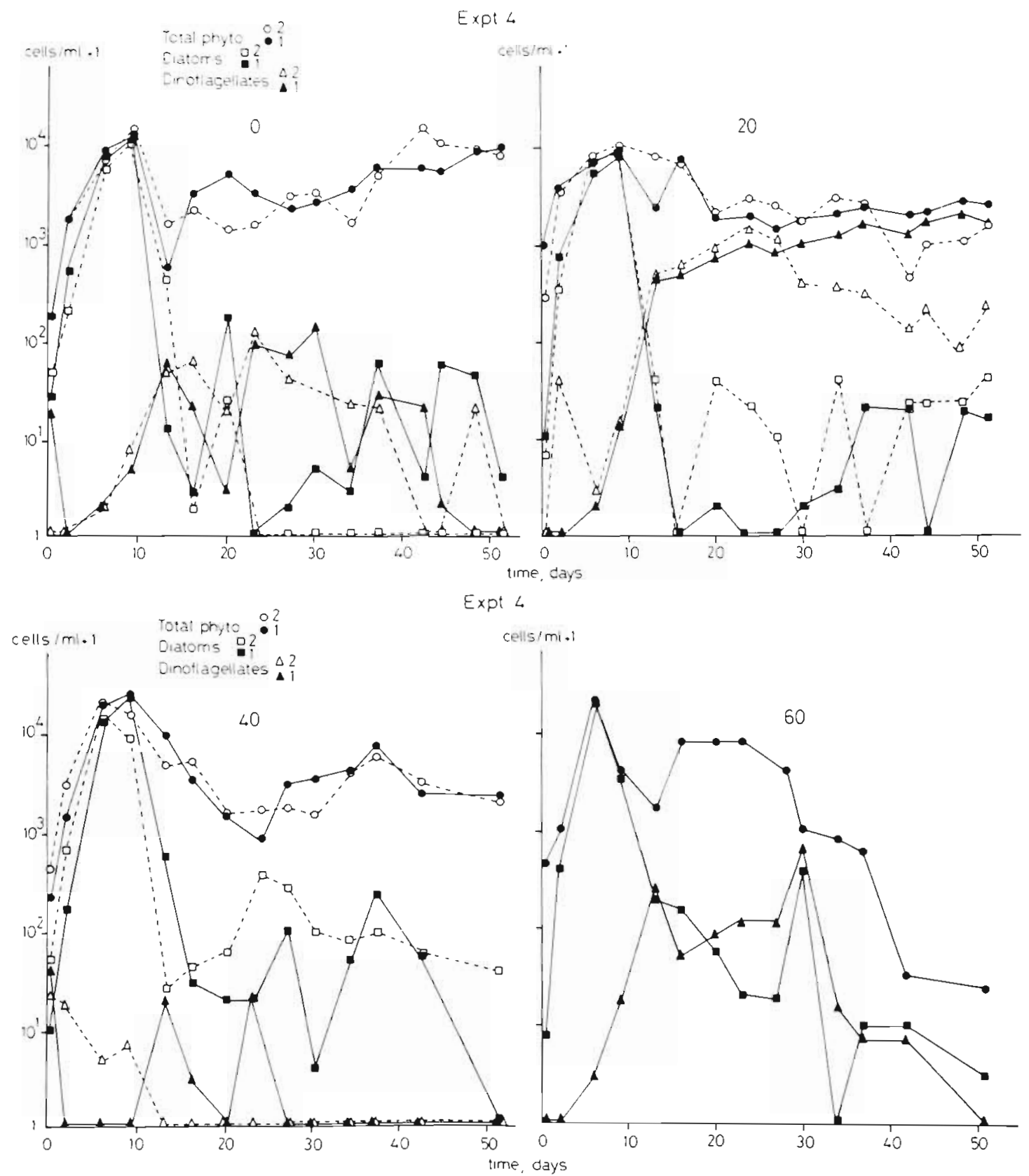

Fig. 8. Expt 4. Temporal variation of concentration of total phytoplankton, diatoms and dinoflagellates at $40 \mathrm{~cm}$ depth in the unstirred (S0) and stirred (S20, S40 and S60) tubes

\section{Expt 3}

Taxa included in the analysis are listed in Table 2. The variance explained by the first 3 components was $34.9,9.9$ and $9.1 \%$ of the total. As can be seen in Table 2 , the first component was positively correlated with several diatoms (Chaetoceros cf. simplex, Leptocylindrus danicus, Nitzschia sp.) presenting high abundances in the initial population; the forms negatively correlated with this component were those dominating in advanced phases of the experiment. The most distinctive feature of the second component was its negative correlation with Skeletonema costatum. The third component separated highly motile organisms such as a Mesodinium rubrum-like ciliate and the dinoflagellate Prorocentrum micans from the remaining taxa.

As can be seen in Fig. 9, temporal variation of the values of the first component, showing a progressive decrease of the scores, was similar in all the tubes of the experiment. However, the second component scores 
Table 2. Expt 3. Correlation coefficients of the 24 taxa selected for analysis with the first 3 principal components. Species ordered according to their correlation coefficient with PC 1

\begin{tabular}{|c|c|c|c|}
\hline \multirow[t]{2}{*}{ Taxon } & \multicolumn{3}{|c|}{ Components } \\
\hline & 1 & 2 & 3 \\
\hline Scrippsiella cf trochoidea & 0.84 & 0.06 & 0.03 \\
\hline Chaetoceros cf. simplex & 0.82 & -0.23 & -0.20 \\
\hline Mesodinium rubrum? & 0.80 & -0.10 & -0.30 \\
\hline Leptocylindrus danicus & 0.77 & 0.48 & 0.16 \\
\hline Cryptomonads & 0.74 & 0.29 & 0.10 \\
\hline Eutreptiella? & 0.74 & 0.29 & -0.27 \\
\hline Cerataulina bergoni & 0.72 & 0.43 & -0.07 \\
\hline Nitzschia 'delicatissima-like' & 0.69 & 0.20 & -0.06 \\
\hline Protoperidinium spp. & 0.66 & -0.19 & -0.11 \\
\hline $\begin{array}{l}\text { 'Green flagellates' } \\
\text { (chlorophytes) }\end{array}$ & 0.50 & -0.10 & 0.18 \\
\hline Flagellates & 0.45 & 0.22 & 0.60 \\
\hline Ciliates & 0.42 & -0.25 & 0.64 \\
\hline Unidentified gymnodinioid & 0.32 & 0.27 & 0.34 \\
\hline Small dinoflagellates & 0.19 & 0.50 & 0.34 \\
\hline Skeletonema costatum & 0.13 & -0.70 & 0.20 \\
\hline Chrysochromulina spp. small & -0.19 & 0.25 & 0.58 \\
\hline Prorocentrum micans & -0.20 & 0.47 & -0.50 \\
\hline Protoperidinium diabolus & -0.31 & -0.24 & 0.42 \\
\hline Amphidinium sp. & -0.45 & 0.21 & 0.01 \\
\hline Pennate diatoms & -0.55 & 0.15 & 0.04 \\
\hline Diplopeltopsis minor? & -0.61 & 0.09 & -0.08 \\
\hline Cylindrotheca closterium & -0.61 & 0.14 & 0.24 \\
\hline Unidentified peridinioid & -0.63 & 0.32 & 0.07 \\
\hline Chrysochromulina spp. large & -0.81 & 0.42 & -0.05 \\
\hline Variance explained & $35 \%$ & $10 \%$ & $9 \%$ \\
\hline
\end{tabular}

were more negative in the unstirred tubes, reflecting the higher concentration of the diatom Skeletonema costatum. The behaviour of the third component was comparable to that of the chlorophyll concentration and the abundance of Prorocentrum micans, which was strongly correlated with the component; all these variables showed a maximum in the $\mathrm{S} 70$ tubes between the 3 rd and 11 th days. The relatively large size of $P$. micans may justify a significant contribution to the total chlorophyll concentration.

\section{Expt 4}

For the analysis of this experiment we selected 21 taxa. The first component of Expt 4, explaining $26 \%$ of the total variance, was associated (with negative correlation, in this case), with the dominant organisms of the initial population, which were almost exclusively diatoms (Table 3): Chaetoceros curvisetus, Thalassiosira spp., Skeletonema costatum, Lauderia borealis, Thalassionema nitzschioides and Licmophora sp., among others; the forms with higher positive correlation with this component were Cylindrotheca (Nitzschia) closterium and small haptophytes and dinoflagellates. Six to $9 \mathrm{~d}$ after the start of the experiment, the first component showed a minimum (Fig. 10) reflecting the development of the centric diatoms which formed the bulk of the initial biomass peak. The low absolute values of the first component in the first samples of the S40 tubes did not correspond to a lower diatom abundance (mainly contributed by $S$. costatum) but to the participation of a smaller number of species.

The highest positive correlations with the second component corresponded to a series of dinoflagellates (Protoperidinium sp. 145, Scrippsiella cf. trochoidea, 'small dinoflagellates', non-identified gymnodinioid no. 509); the most significant negative correlation was presented by a choanoflagellate, tentatively identified as Desmarella moniliformis. The behaviour of the second component (Fig. 10) showed consistent differences related to the stirring treatments. During practically the entire experiment, the scores of this component were highest in the $\$ 20$ tubes, reflecting the greater dinoflagellate abundance and number of taxa in these tubes. The lowest second component scores corresponded to the S40 tubes.

The third component showed the highest positive correlations (Table 3) with Emiliania huxleyi and several groups of flagellates. In general, the scores of this component reached a maximum between Days 14 and 24.

Table 3. Expt 4. Correlation coefficients of the 21 taxa selected for analysis with the first 3 principal components. Species ordered according to their correlation coefficient with PC 1

\begin{tabular}{|c|c|c|c|}
\hline \multirow[t]{2}{*}{ Taxon } & \multicolumn{3}{|c|}{ Components } \\
\hline & 1 & 2 & 3 \\
\hline Unidentified gymnodinioid 509 & 0.59 & 0.52 & -0.37 \\
\hline Ciliate 503 & 0.49 & 0.51 & -0.40 \\
\hline Protoperidinium sp. 145 & 0.38 & 0.79 & -0.08 \\
\hline Scrippsiella cf. trochoidea & 0.38 & 0.66 & 0.19 \\
\hline Chrysochromulina spp. & 0.36 & 0.28 & 0.40 \\
\hline Small dinoflagellates & 0.35 & 0.67 & 0.14 \\
\hline Ciliates & 0.31 & 0.05 & 0.00 \\
\hline Emiliania huxleyi & 0.29 & 0.48 & 0.34 \\
\hline Pyramimonas sp. & 0.19 & 0.48 & 0.42 \\
\hline Cylindrotheca closterium & 0.16 & -0.14 & -0.14 \\
\hline $\begin{array}{l}\text { Desmarella moniliformis? } \\
\text { (choanoflagellate) }\end{array}$ & 0.12 & -0.56 & 0.14 \\
\hline Prorocentrum micans & 0.09 & 0.41 & -0.22 \\
\hline Cryptomonads & -0.21 & 0.18 & 0.56 \\
\hline Flagellates & -0.26 & 0.01 & 0.80 \\
\hline Pennate diatoms & -0.42 & -0.01 & 0.12 \\
\hline Licmophora sp. & -0.61 & 0.35 & -0.11 \\
\hline Chaetoceros curvisetus & -0.78 & 0.31 & -0.13 \\
\hline Thalassionema nitzschioides & -0.83 & 0.37 & -0.19 \\
\hline Lauderia annulata & -0.84 & 0.40 & -0.13 \\
\hline Thalassiosira spp. & -0.86 & 0.36 & 0.01 \\
\hline Skeletonema costatum & -0.87 & 0.21 & 0.02 \\
\hline Variance explained & $26 \%$ & $18 \%$ & $10 \%$ \\
\hline
\end{tabular}



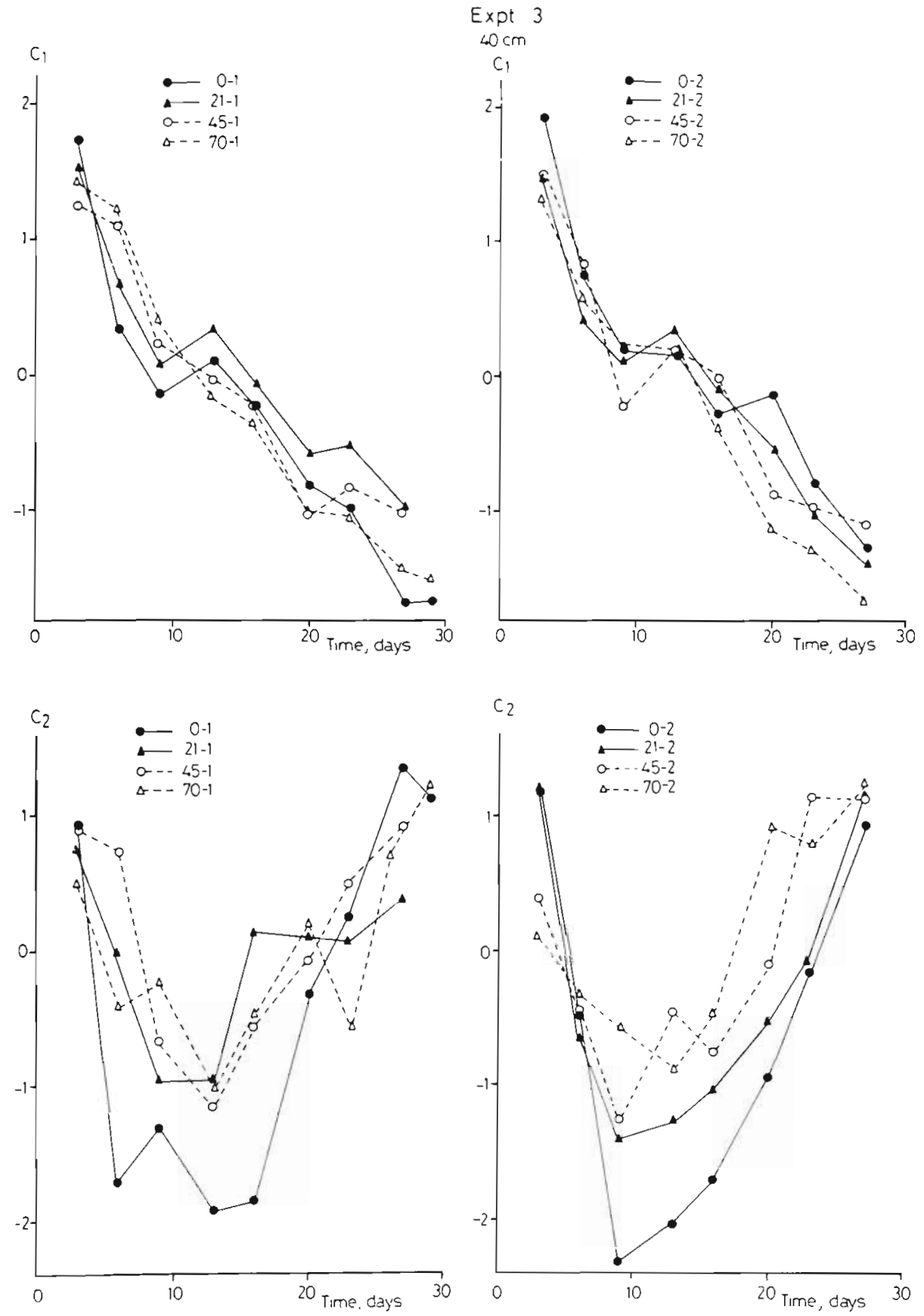

Fig. 9. Expt $3 ; 40 \mathrm{~cm}$ samples. Temporal variation of values of first principal component (above) and second principal component (below) for the first duplicate (left) and second duplicate (right) of the unstirred (S0) and stirred (S21, S45 and 570 ) tubes

\section{Influence of the initial population}

The principal component analysis performed on the $40 \mathrm{~cm}$ data set of the S0 and S40 tubes of the 4 experiments (Fig. 11 \& 12) separated the variations linked with phytoplankton succession in the tubes (Component 2 in the figure) from effects related to the composition of the initial population (Component 1). The differences in phytoplankton composition related to the stirring treatments were less important sources of variance in the pooled data set. As can be seen in Fig. 12, Expts 3 and 6, started in June, during the summer stratification period, showed positive values of Component 1, while Expts 4 and 5, started during the mixing period, presented negative values. The higher scores of Component 1 for Expts 3 and 6 respond (Fig. 11) principally to a greater proportion of relatively large dinoflagellates (Scrippsiella cf. trochoided, Prorocentrum micans, Protoperidinium spp.) and other highly motile organisms. The trajectories of Component 2 

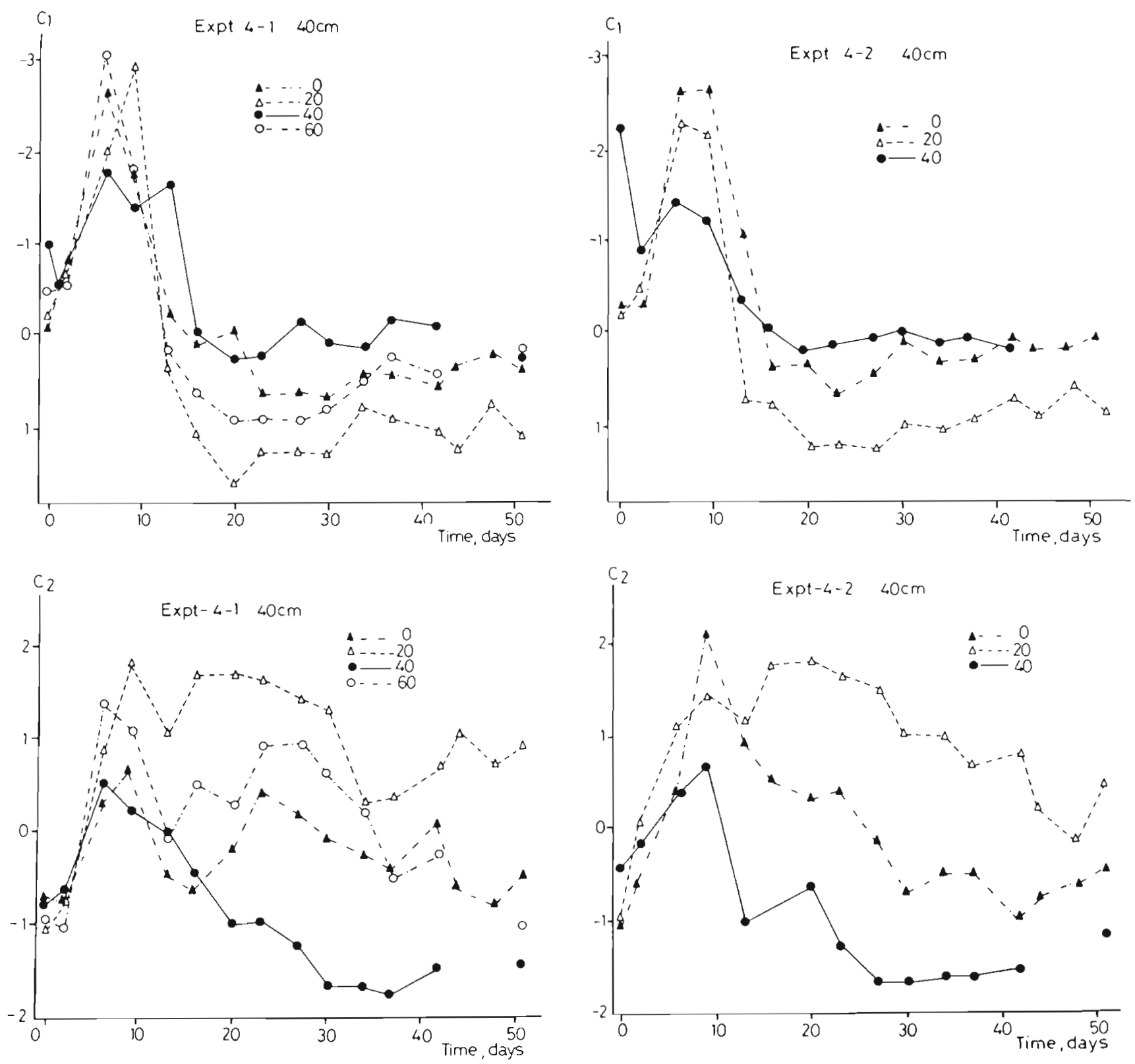

Fig. 10. Expt 4;40 cm samples. Temporal variation of values of first principal component (above) and second principal component (below) for the first duplicate (left) and second duplicate (right) of the unstirred (SO) and stirred ( $\mathrm{S} 20, \mathrm{~S} 40$ and S60) tubes. The scale of the first component has been reversed

along Expts 4 and 5 reflect the initial bloom of diatoms in these experiments.

The results of a canonical analysis applied to a data set similar (except for the last samples of the longest experiments) to that included in the previous principal component analysis are shown in Fig. 13 and Table 4. As in the case of the principal components, the first canonical variate separated Expts 3 and 6 from 4 and 5, on the basis of the participation of several large dinoflagellate species in the experiments started in June. The second canonical variate reached highest values in Expts 3 and 5. The differences expressed by this variate were related to variations in the contribution of Pterosperma sp., Emiliania huxleyi and a series of diatoms and dinoflagellates (Table 4). The populations of the unstirred and stirred tubes appeared clearly separated in Expts 4 and 6.

\section{DISCUSSION}

The preliminary estimates of the vertical diffusion coefficient in stirred and non-stirred tubes lie in the range of published values for natural environments 


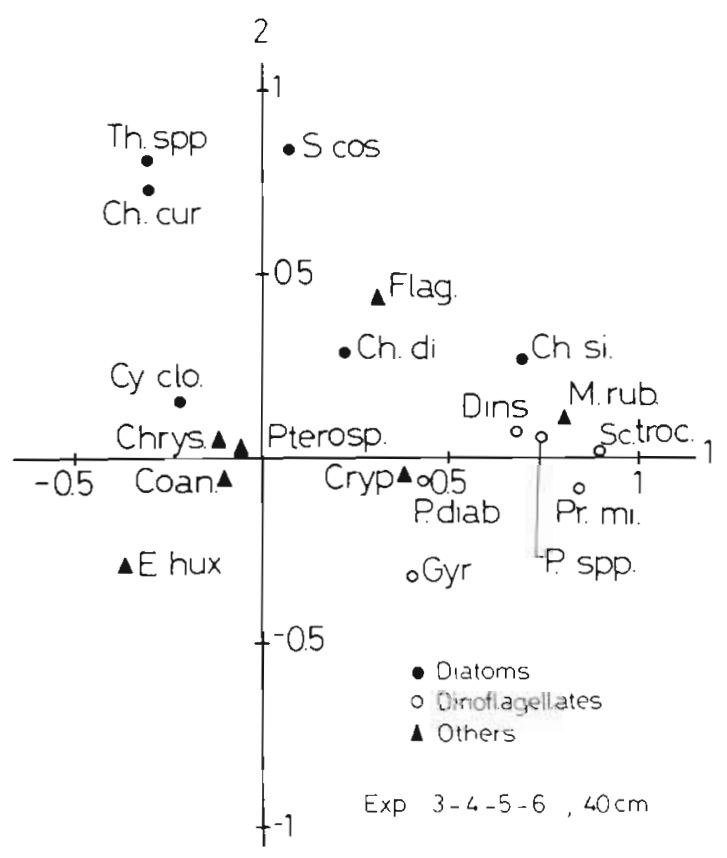

Fig. 11. Pooled data of Expts 3, 4, 5 and $6 ; 40 \mathrm{~cm}$ samples. Position of the extremes of the 19 vectors in the space determined by the first and second principal components. Key: Ch. cur. = Chaetoceros curvisetus; Ch. di. = Chaetoceros didymus; $\mathrm{Ch}$. si. = Chaetoceros cf. simplex; Chrys. $=$ Chrysochromulina-like haptophytes; Coan: Desmarella moniliformis (choanoflagellate); Cryp. = cryptomonads; Cy. clo. = Cylindrotheca closterium; Dins. = small dinoflagellates; E. hux. = Emiliania huxleyi; Flag. = flagellates; Gyr. = Gyrodinium spp.; M. rub. = Mesodinium rubrum; P. diab.: Protoperidinium diabolus; P. spp.: Protoperidinium spp.; Pr. mi. = Prorocentrum micans; Pterosp. = Pterosperma sp.; Sc. troc. $=$ Scrippsiella of. trochoides; S. cos. = Skeletonema costatum; Th. spp. = Thalassiosira spp.

(Kullenberg 1974, 1978, Needler \& Heath 1975, Tett \& Edwards 1984), but it is difficult to make comparisons. Although the proper physical representation of turbulence is still a problem, turbulent motions are often treated as including a range of different length scales, which in the upper end may be indistinguishable from advection. The constancy of the external forcing and the boundary conditions in the microcosms eliminate a large part of the temporal and spatial scales of the turbulence spectrum that may occur in the sea; due to this fact and to the virtual absence of nutrient inputs, the phytoplankters in our microcosms experienced only a small part of the ecological space represented by diagrams such as those of Margalef et al. (1979) or Pingree (1978). However, as pointed out by Margalef (1978), small-scale turbulent motions may have important implications in relation with phytoplankton strategies, so that understanding the effects of these motions is a relevant ecological problem.

In all the experiments, the confinement of the phytoplankton populations in the tubes triggers a sequence of events which depends on the initial conditions and may be modulated in a repeatable way by the treatments applied to the microcosms. The initial blooms of fast-growing centric diatoms have been reported in other enclosure experiments (e.g. Grice et al. 1977 . Eppley et al. 1978, Parsons et al. 1978, Davis 1982) using containers of different volumes. The diatoms forming the bulk of the initial population peak consume the available nutrients and sink to the bottom; in the late phases of our experiments they disappear from the medium, with the exception of moderate proliferations of Cylindrotheca closterium and other small forms like Thalassiosira sp. and, in some cases, even Skeletonema costatum. In the end, the microcosm is left with chlorophyll concentrations not very different from the starting ones, but with lower (sometimes much lower) nutrient concentrations reflecting, presumably, the change to a mode of functioning with more heterotrophic biomass and higher recycling activity.

The most pronounced differences in the taxonomic composition of the phytoplankton populations subjected to different stirring treatments occur after the initial changes. In later stages of the experiments, dinoflagellates were the group showing the most characteristic responses to the various treatments (of course, changes in the taxa pooled as non-identified flagellates' may have been overlooked). Several mechanims related to the mixing of the medium could have influenced the organisms. The assimilation of nutrients may be favoured by the destruction of diffusion gradients due to turbulence (Gavis 1976). Kilham \& Kilham (1980) and Harrison \& Turpin (1982) have suggested that specific nutrient flux is important in determining dominance of different phytoplankton groups. In this context, they view the results of changing physical factors through effects on the nutrient demand/supply ratio of the different phytoplankters. Turbulence could also affect the physiological state of the cells (Pollinger \& Zemel 1981). White (1976) reports that intense stirring of the medium had deleterious consequences for Gonyaulax excavata. Other effects of the intensity of mixing include changes in the distribution and net sinking rates of the organisms and modification of their patterns of exposure to irradiance and temperature in the water column. The temperature changes in the photic zone of the tubes were small and not likely to have affected phytoplankton growth rates to a large extent. However, under the conditions of our experiments, possible effects of the different irradiance regimes experienced by the cells under the various treatments cannot be separated from other effects of turbulence, as happens also in natural situations. The turbulence conditions in the tubes may have affected, directly or indirectly, the swimming patterns and migratory behaviour of the dinoflagellates (Kamykowski 


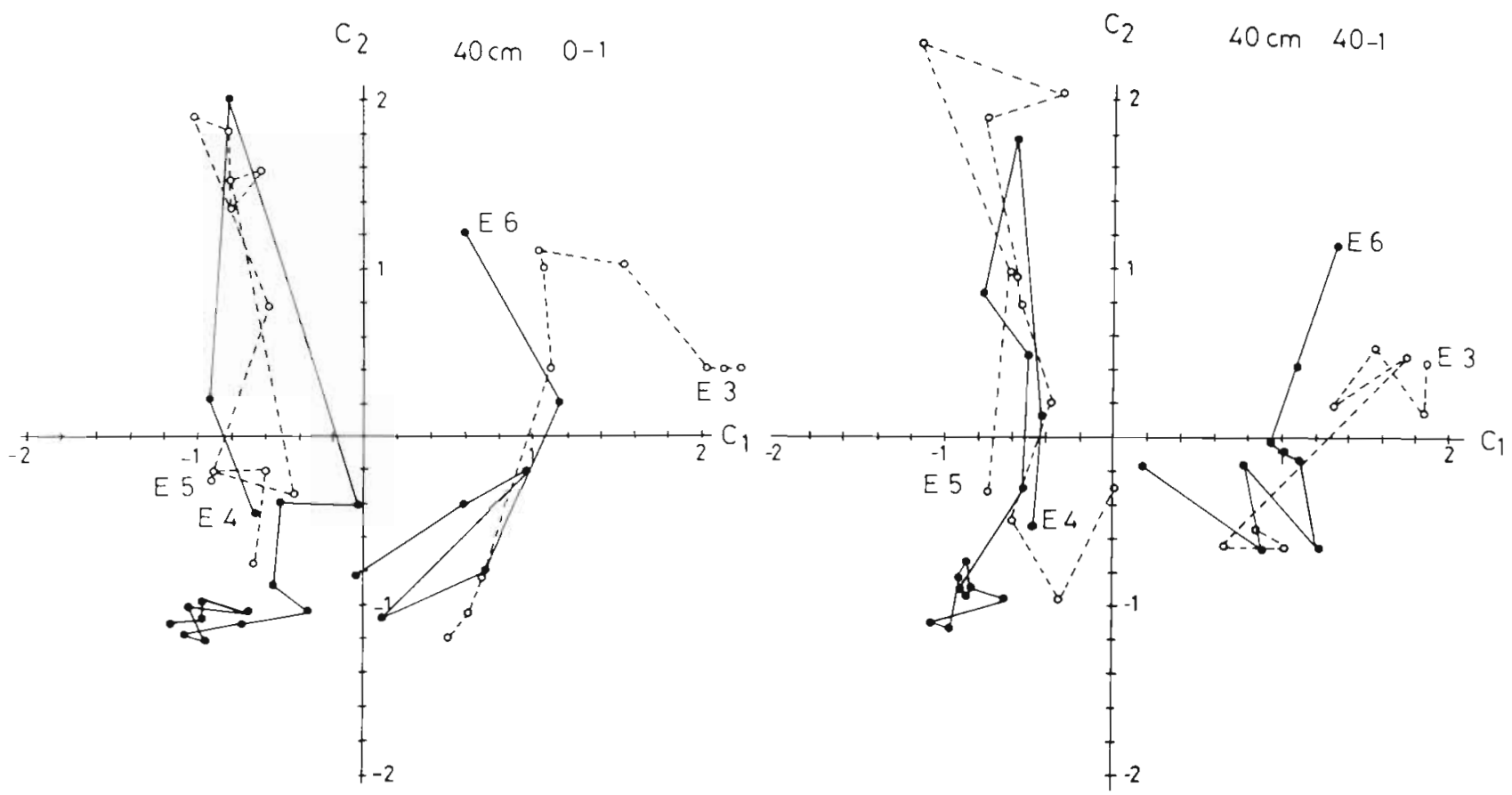

Fig. 12. Pooled data of Expts 3, 4,5 and 6;40 cm samples. Trajectories of the samples in the space of the 2 first principal components. Left: First duplicate of the unstirred tubes. Right: First duplicate of the stirred tubes. Letter E with the numbers (3, 4, 5 and 6 ) indicates the first sample of the corresponding experiment

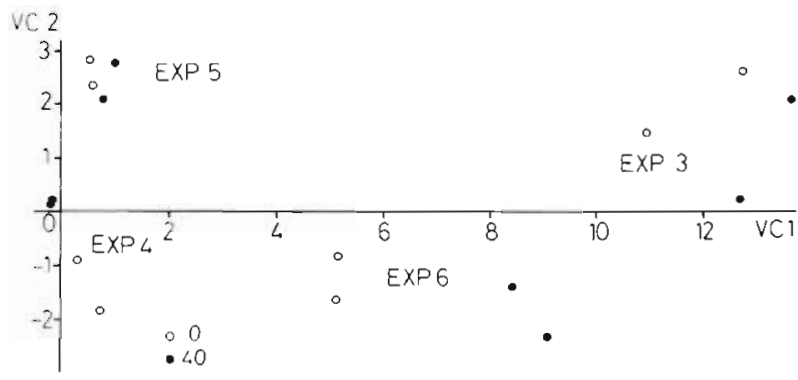

Fig. 13. Pooled data of Expts 3,4,5 and 6; $40 \mathrm{~cm}$ samples. Position of the populations in the space of the 2 first canonical axes

\& Zentara 1977, Cullen \& Horrigan 1981, Heaney \& Eppley 1981); this could help to explain the selective effects of some stirring treatments. In Expt 3 (Marrasé unpubl. data) we observed that during light hours Prorocentrum micans was distributed differently in stirred and non-stirred tubes. A question that can be raised, given that only 2 depths were sampled, is to what extent the observed changes in the dinoflagellate population were due to variations in the overall abundance of the species or in their distribution along the tubes. Although some distribution effects may have been present, we think that they cannot explain completely the reported results. Although perhaps possible in principle, it is unlikely that the several dinoflagellate taxa concerned would have coincided in concentrating at the same time of the day in some part of the tubes, escaping our sampling completely. Some additional samples taken within the thermocline during Expts 5 and 6 had a phytoplankton composition comparable to those taken at 40 and $145 \mathrm{~cm}$.

Successional patterns in the tubes conformed to the regularities identified by Margalef (1958), but the ini-

Table 4. Structure coefficients of canonical population analysis of data set shown in Fig. 13

\begin{tabular}{|lcc|}
\hline Variable & $\begin{array}{c}\text { First } \\
\text { canonical } \\
\text { axis }(77.7 \% \\
\text { of variance) }\end{array}$ & $\begin{array}{c}\text { Second } \\
\text { canonical } \\
\text { of }(11.1 \%\end{array}$ \\
\hline 1. Gyriance)
\end{tabular}


tial conditions had a relatively predictable influence (Fig. 12 \& 13) on the composition of the phytoplankton communities developed in the tubes. Examination of Table 1 suggests that the starting populations of Expts 3 and 6 , with a greater proportion of dinoflagellates and higher cell and chlorophyll concentrations, were in a more advanced stage of succession that those of Expts 4 and 5. Although there is no information on the annual cycle of phytoplankton in Masnou Harbour, the proposed interpretation agrees well with published data on seasonal cycles on the Catalan coast (Margalef \& Castellví 1967).

Taking into account the obvious differences in temporal and spatial scales, the initial diatom bloom in the tubes with relatively low chlorophyll and high nutrient concentrations can be compared with the typical 'spring blooms' of temperate seas, which include a series of centric diatoms quoted by Margalef (1958) as characterizing the first stages of the phytoplankton succession. The relationship of spring blooms to seasonal variations in water column stability and incident irradiance was already recognized by Gran \& Braarud (1935); the reduction of the mixing layer with the establishment of the thermocline decreases the time spent by the cells in dark zones and allows net growth to take place. However, there is no general agreement concerning the relative importance of the processes contributing to the appearance of spring phytoplankton blooms. The enclosure of a phytoplankton population in a microcosm may vary the light conditions or other factors (like the concentration of predators, according to Perez et al. 1977) and allow an increase in the growth rate of the phytoplankton. However, the finding that the initial population peak occurs independently of the stirring treatments and under a great variety of light environments or predator concentrations (Alcaraz et al. in press) suggests that the underlying causes are of a more general character Possibly, one of the most important effects of the containment of a phytoplankton community into a limited volume are the initial mixing and a reduction of the loss of cells by physical transport.

Acknowledgements. This work was supported by the Comisión Asesora de Investigación Científica y Técnica and the Consejo Superior de Investigaciones Científicas. We are grateful to Dr R. Margalef for his suggestions and comments and to Mr Barrenechea, director of the Nautical Harbour of Masnou, for the facilities given to us. We thank also Mr A. Fauquet for his help in designing the experimental setup. Miss C. Bas, Mr J. Biosca, Mrs A. Cruz and Miss R. Ras provided technicàl assistance.

\section{LITERATURE CITED}

Alcaraz, M., Estrada, M., Marrasé, C. (in press). Interaction between turbulence and zooplankton in laboratory micro- cosms. Proceedings of the 21st European Marine Biology Symposium, Gdansk, Poland

Allen, T F., Koonce, J. F. (1973). Multivariate approaches to algal stratagems and tactics in systems analysis of phytoplankton. Ecology 54: 1234-1246

Blasco, D. (1971). Acumulación de nitritos en determinados niveles marinos por acción del fitoplancton. Ph. D. thesis, University of Barcelona, Barcelona

Blasco, D., Estrada, M., Jones, B. H. (1981). Short time variability of phytoplankton populations in upwelling regions. The example of northwest Africa. In: Richards, F. A. (ed.) Coastal upwelling. American Geophysical Union, Washington, p. 339-347

Bowman, M. J., Esaias, W. E., Schnitzer, M. B. (1981). Tidal stirring and the distribution of phytoplankton in Long Island and Block Island Sounds. J. mar. Res. 39: 586-603

Cooley, W. W., Lohnes, P. R. (1971). Multivariate data analysis. Wiley, New York

Cuadras, C. M. (1981). Métodos de análisis multivariante. Eunibar, Barcelona

Cullen, J. J., Horrigan, S. G. (1981). Effects of nitrate on the diurnal vertical migration, carbon to nitrogen ratio and the photosynthetic capacity of the dinoflagellate Gymnodinium splendens. Mar. Biol. 62: 81-89

Davis, C. O. (1982). The importance of understanding phytoplankton life strategies in the design of enclosure experiments. In: Grice, G. D., Reeve, M. R. (ed.) Marine mesocosms. Biological and chemical research in experimental ecosystems. Springer-Verlag, New York, p. 323-332

Eppley, R. W., Koeller, P., Wallace, Jr., G. T. (1978). Stirring influences the phytoplankton species composition within enclosed columns of coastal sea water. J. exp. mar Biol. Ecol. 32: 219-239

Estrada, M. (1976). Estudios sobre poblaciones de organismos acuáticos en medio no uniforme. Ph. D. thesis, University of Barcelona, Barcelona

Estrada, M. (1982). Phytoplankton of the Western Mediterranean at the beginning of autumn. Int. Revue ges. Hydrobiol. 67: 517-532

Gamble, J. C., Davies, J. M. (1982). Application of enclosures to the study of marine pelagic systems. In: Grice, G. D., Reeve, M. R. (ed.) Marine mesocosms. Biological and chemical research in experimental ecosystem. SpringerVerlag, New York, p. 25-48

Gavis, J (1976). Munk and Riley revisited: rutrient diffusion transport and rates of phytoplankton growth. J. mar. Res. 34: $161-179$

Gran, H. H., Braarud, T. (1935). A quantitative study of the phytoplankton in the Bay of Fundy and the Gulf of Maine (including observations on hydrography, chemistry and turbidity). J. biol. Bd Can. 1: 279-467

Grice, G. D., Harris, R. P., Reeve, M. R., Heinbokel, J. F., Davis, C. O. (1980). Large scale enclosed water-column ecosystems: an overview of Foodweb I, the final CEPEX experiment. J. mar biol. Ass. U. K. 60: 401-414

Grice, G. D.. Reeve, M. R., Koeller, P., Menzel, D. W (1977). The use of large volume, transparent, enclosed sea-surface columns in the study of stress in plankton ecosysterns. Helgoländer wiss. Meeresunters. 30: 118-133

Harris, G. P. (1983). Mixed layer physics and phytoplankton populations: studies in equilibrium and non-equilibrium ecology. In: Round, F. E., Chapman, D. J. (ed.) Progress in phycological research, Vol. II. Elsevier, Amsterdam, p. $1-86$

Harrison, P. J., Turpin, D. H. (1982). The manipulation of physical, chemical and biological factors to select species from natural phytoplankton communities. In: Grice, G. D. 
Reeve, M. R. (ed.) Marine mesocosms. Biological and chemical research in experimental ecosystems. SpringerVerlag, New York, p. 323-332

Heaney, S. S., Eppley, R. W. (1981). Light, temperature and nutrition as interacting factors affecting diel vertical migration of dinoflagellates in culture. J. Plankton Res. 3: 331-344

IBM (1969). Scientific subroutine package (1130-CM-02X). Programmer's Manual, IBM Corporation, White Plains, New York

Jitts, H. R., McAllister, C. D., Stephens, K., Strickland, J. D. H. (1964). The cell division rates of some marine phytoplankters as a function of light and temperature. J. Fish. Res. Bd Can. 21: 139-157

Jörgensen, E. (1968). The adaptation of plankton algae. II. Aspects of the temperature adaption of Skeletonema costatum. Physiologia Pl. 21: 423-427

Kamykowski, D., Zentara, S. J. (1977). The diurnal vertical migration of motile phytoplankton through temperature gradients. Limnol. Oceanogr. 22: 148-151

Kilham, P., Kilham, S. S. (1980). The evolutionary ecology of phytoplankton. In: Morris, I. (ed.) The physiological ecology of phytoplankton. Blackwell, Oxford, p. 571-597

Kullenberg, G. (1974). An experimental and theoretical investigation of the turbulent diffusion in the upper layer of the sea. Institut for Fysisk Oceanografi, University of Copenhagen, Rep. No. 25

Kullenberg, G. (1978). Vertical processes and the verticalhorizontal coupling. In: Stelle, J. H. (ed.) Spatial pattern in plankton communities. Plenum Press, New York, p. $181-220$

Legendre, L., Legendre P. (1983). Numerical ecology. Elsevier, Amsterdam

Margalef, R. (1958). Temporal succession and spatial heterogeneity in phytoplankton. In: Buzzati-Traverso, A. A. (ed.) Perspectives in marine biology. Univ. of California Press, Berkeley, p. 323-349

Margalef, R. (1963). Modelos simplificados del ambiente marino para el estudio de la sucesión y distribución del fitoplancton y del valor indicador de sus pigmentos. Investigación pesq. $23: 11-52$

Margalef, R. (1972). Fitoplancton de la región de afloramiento del noroeste de Africa. Res. Exp. Cient. B/O Cornide 1: 23-51

Margalef, R. (1978). Life-forms of phytoplankton as survival alternatives in an unstable environment. Oceanologica Acta 1: 493-509

Margalef, R., Castellví, J. (1967). Fitoplancton y producción primaria de la costa catalana de julio de 1966 a julio de 1967 Investigación pesq. 31: 491-502

Margalef, R., Estrada, M., Blasco, D. (1979). Functional morphology of organisms involved in red tides, as adapted to decaying turbulence. In: Taylor, D. L., Seliger, H. H. (ed.) Toxic dinoflagellate blooms. Elsevier/North Holland, New York, p. 89-94

Marrasé, C. (1986). Experimentos multifactoriales con plancton marino en microcosmos. Ph. D. thesis, Univ. of Barcelona, Barcelona

Morris, I. (1980). The physiological ecology of phytoplankton. Blackwell, Oxford

Needler, G. T., Heath, R. A. (1975). Diffusion coefficients calculated from the Mediterranean salinity anomaly. J. phys. Oceanogr. 5: 173-182
Nixon, S. W., Alonso, D., Pilson, M. E. Q. Buckley, B. A. (1980). Turbulent mixing in aquatic microcosms. In: Giesy, J. P. (ed.) Microcosms in ecological research. Technical Information Center, U.S. Dept. of Energy, Springfield, Virginia, p. 818-849

Oviatt, C. A. (1981). Effects of different mixing schedules on phytoplankton, zooplankton and nutrients in marine microcosms. Mar. Ecol. Prog. Ser. 4: 57-67

Oviatt, C. A., Walker, H., Pilson, M. E. Q. (1980). An exploratory analysis of microcosm and ecosystem behaviour using multivariate techniques. Mar. Ecol. Prog. Ser. 2: 179-191

Okubo, A. (1976). Remarks on the use of ,diffusion diagrams in modeling scale-dependent diffusion. Deep Sea Res. 23: 1213-1214

Parsons, T. R., Harrison, P. J., Waters, R. (1978). An experimental simulation of changes in diatoms and flagellate blooms. J. exp. mar. Biol. Ecol. 32: 285-294

Perez, K. T., Morrison, G. M., Lackie, N. F., Oviatt, C. A., Nixon, S. W., Buckley, B. A., Heltshe, J. F. (1977). The importance of physical and biotic scaling to the experimental simulation of a coastal marine ecosystem. Helgoländer wiss. Meeresunters. 30: 144-162

Pilson, M. E. Q., Nixon, S. W (1980). Marine microcosms in ecological research. In: Giesy, J. P. (ed.) Microcosms in ecological research. Technical Information Center, U. S. Dept. of Energy, Springfield, Virginia, p. 724-741

Pingree, R. D. (1978). Mixing and stabilization of phytoplankton distributions on the northwest european continental shelf. In: Steele, J. H. (ed.) Spatial patterns in plankton communities. Plenum Press, New York, p. 181-220

Pollinger, J., Zemel, E. (1981). In situ experimental evidence of the influence of turbulence on cell division processes of Peridinium cinctum forma westii (Lemm.) Lefevre. Br. Phycol. J. 16: 281-287

Redfield, A. C. (1958). The biological control of chemical factors in the environment. Am. Scient. 46: 205-221

Reynolds, C. S., Wiseman, S. W., Godfrey, B. M., Butterwich, C. (1983). Some effects of artificial mixing on the dynamics of phytoplankton populations in large limnetic enclosures. J. Plankton Res. 5: 203-234

Savidge, G. (1981). Studies of the effects of small-scale turbulence on phytoplankton. J. mar. biol. Ass. U. K. 61: $477-488$

Schöne, H. (1970). Untersuchungen zur ökologischen Bedeutung des Seegangs für das Plankton mit besonderer Berücksichtigung mariner Kieselalgen. Int. Revue ges. Hydrobiol. 55: 595-677

Sonntag, N. C., Parsons, T R. (1979). Mixing an enclosed, $1300 \mathrm{~m}^{3}$ water column: effects on the planktonic food web. J. Plankton Res. 1: 85-102

Strickland, J. D. H, Parsons, T. R. (1972). A practical handbook of seawater analysis, 2nd edn. Bull. Fish. Res. Bd Can. 167: $1-310$

Tett, P., Edwards, A. (1984). Mixing and plankton: an interdisciplinary theme in oceanography. Oceanogr. mar. Biol. A. Rev. 22: 99-123

White, A. W. (1976). Growth inhibition caused by turbulence in the toxic marine dinoflagellate Gonyaulax excavata. J Fish. Res. Bd Can. 33: 2598-2602

Yentsch, C. S., Menzel, D. W. (1963). A method for the determination of phytoplankton chlorophyll and phaeophytin by fluorescence. Deep Sea Res. 10: 221-231 